\title{
Government Public Relations and Broadcast Regulation: Evaluating Electronic Media Regulations in South Asia
}

\author{
AZMAT RASUL \\ Florida State University, USA
}

In South Asia, the public relations departments of the Indian and Pakistani governments have been playing a critical role in the making of broadcast regulation policies and enactment of media laws, which helped successive governments and bureaucracies intervene in the business and functioning of the companies providing electronic media services to millions of people in the region. The regulatory processes and enactment of laws governing electronic media help public relations departments of various regional governments maintain their control over the content and routine operations of media organizations. This article examines why and how bureaucratic powers have hampered the process of broadcast regulation in India and Pakistan. The comparison is heuristically significant despite social and political differences between Pakistan and India, as both countries have inherited similar laws governing broadcasting from the British colonial rule and most of the pre-partition regulations are still in place. The article concludes that a great deal of political effort is required to establish independent regulatory authorities in both countries due to the overarching control of bureaucracies in both societies.

Keywords: Normative theories, broadcast regulation, communication industry, diversity, media laws

With the unprecedented growth of electronic media in the South Asian region, devising effective regulatory mechanisms and policies has emerged as a considerable challenge. In South Asia, regulatory authorities and communication policymakers espoused a propensity to maintain strong and often indirect control on the operations of independent media due to their capacity to influence social, cultural, and political structures of the society (Creech, 2013; Gupta, 2015; Napoli, 2003). Traditional press and newly liberated electronic media have been challenging the authority of various South Asian governments, which, in turn, consider maverick media a dangerous weapon that should be managed in the name of public interest (Ameer, 2014; McChesney, 2008; Napoli, 2003). Contrariwise, media practitioners and owners struggle to uphold their independence, impartiality, and economic viability and often criticize regulatory practices introduced by democratic and despotic governments in various countries of South Asia (Price, Rozumilowicz, \& Verhulst, 2003; Richter, 2016). Continual interference of the policymakers breeds tension between electronic media industries and the governments, which generates controversies and heated debates regarding electronic media regulation. The uneasy relationship between policymakers and electronic media opens an exciting research window for the comparative analysis of

Correspondence to: Azmat Rasul, School of Communication, Florida State University, Tallahassee FL 32306, USA. 
policymaking processes in South Asia, which remain under-researched in the current academic literature. To address this gap, the current study examines the role public-sector regulators have played in facilitating the proliferation of electronic media fulfilling informative, educational, and entertainment needs of approximately two billion people in two major countries in the South Asian region: India and Pakistan.

To examine the role policymakers played in dealing with the regulation complexities, this comparative case study brings off exploratory research by evaluating multifarious regulato ry interventions by successive governments in India and Pakistan. Both countries shared historical and cultural similarities and inherited Ministries of Information from the British Raj, which were used by various governments to keep an eye on the "rogue" elements in the media industry (Niazi, 2003; Author removed, 2013). The tight control of $M$ inistries of Information over the information flow remained in effect for a long time after independence in 1947; however, ministerial controls began to lose ground in the last two decades of the $20^{\text {th }}$ century due to globalization, media convergence, and an international environment favoring free flow of information (Creech, 2013). For example, Pakistan Electronic M edia Regulatory Authority (PEM RA) was established in 2002 by the military regime to regulate a burgeoning broadcast media market in Pakistan. India, on the other hand, did not establish a formal regulatory authority to regulate the unprecedented growth of electronic media, which kicked-off in early 1990s after the adoption of liberal economic policies by the Indian government (Thussu, 2006). According to Thussu (1999: 126), the new economic policies "encouraged privatization, dismantling state controls and liberalizing media regulation, paving the way for the entry of global media conglomerates into what used to be one of the most closed broadcasting systems in any democracy." Taking into consideration these developments in the Indian sub-continent, the current study intends to gain a better understanding as to what extent governments influence regulatory policies in India and Pakistan. Specifically, this comparative case study evaluates regulatory initiatives of PEM RA in Pakistan and various legislations facilitating electronic media regulation in India by focusing on the role of M inistries of Information, traditionally known for hampering independent regulatory processes (Napoli, 2003).

\section{Questioning Media Regulation in South Asia}

South Asian countries are impacted by the forces of globalization and new communication technologies, which have changed the dynamics of social, cultural, and political interactions within the region and worldwide (Thussu, 1999). To deal with the challenges of technological innovations and new media industries, governments are interested in benefiting from the experiences of various countries that could help them launch appropriate policy initiatives suitable for their societies (Napoli, 2003; Rasul \& McDowell, 2014). Rasul and McDowell (2014, p.19) argue that "ad hoc, inefficient, and mercurial policy decisions would be taken if policymakers deal with the changing mediascape in an inconsistent manner". Anderson (1992) also suggests that "to make a policy decision, one must invoke some criteria of evaluation" (387). The criteria of evaluation could be different for different countries, and Napoli (2003) argues that researchers have not appropriately analyzed these evaluation criteria or founding principles. It is, therefore, heuristically imperative to evaluate the ways regulatory regimes controlled by the public relations departments adopt efficient and consistent approaches to deal with the private media organizations and new modes of communication in vast and diverse markets such as India and Pakistan. 
If we compare South Asian media regulation exercises with other countries, various models of broadcast media regulation exist depending on the nature of the political system and dispensations of the ruling elite. For example, various scholars (Garry, 1994; Rasul \& M cDowell, 2011) have discussed four media regulatory models, which might be pertinent here: a no-regulation model that deals with print media; a common carrier model governing telegraph and telephone regulation; a public trustee model related to radio and television; and a hybrid model looking after the cable television industry. These models are germane to the South Asian media sphere where media industry experienced manifold growth in the last three decades. Since the middle of 1990s in India and early 2000 in Pakistan, various governments facilitated the growth of private sector television and radio stations, cable television, multinational telecommunication companies, and English and vernacular newspapers and magazines, which were relatively independent and free from the government rheostat contrary to the traditional control over media industries by the public relations department of the government. (Gupta, 2015; Rasul \& M cDowell, 2011; Thussu, 1999).

Considering regulatory dilemmas in South Asia, one can find that various Indian and Pakistani governments have used their public relations departments (M inistries of Information and Broadcasting) to maintain their control over the content of electronic media and to strike a balance between assorted competing actors trying to monopolize the huge media market in the region (Kemal, 2002; Rasul \& M cDowell, 2014). Rasul and M cDowell $(2011$, p. 17) argue that "governments employ market failure and equity considerations as the most important reasons for introducing regulatory regimes." M edia regulation directly influences operations of media companies and consumption of media, as regulations would impact pricing, competition in the media market, media diversity, and hegemony of major media firms (McChesney, 2008). However, the bureaucrats-cum-professionals in the public relations departments of the Ministry of Information in South Asian societies tend to rely on complicated, and sometimes controversial, media laws and regulatory practices to maintain their control over the media market and to deal with adversarial media. This situation is not unique as scholars (Bernstein, 1955; Kemal, 2002; M cChesney, 2008; Napoli, 2003; Rasul \& M cDowell, 2011) agree that media regulators are passionate about facilitating and reforming the media, but they fall a prey to bureaucratic red-tapism and begin to play in the hands of political and economic elite. Political pressure and private sector bribes render regulatory bodies ineffective and force them frame statutes favoring interesting of media moguls (Laffont \& Tirole, 1993; Rasul \& M cDowell, 2011).

As governments dominated by bureaucracies tend to be regressive advocates of status quo (M cChesney, 2008), it is a pertinent question why the successive government in India and Pakistan allowed a proliferation of "unruly" media, which could create serious problems for corrupt politicians and bureaucrats in the power corridors. By attempting to respond to this question, the current project raises new questions, which could contribute to an understanding of the role played by Ministries of Information in India and the Pakistan to liberate media, besides assessing "achievements" of the regulatory mechanisms in attaining their goals. Consequently, the following research questions will be the mainstay of this comparative case study exploring processes of electronic media regulation in India and Pakistan:

RQ1: Did the governments in India and Pakistan establish regulatory regimes facilitating promotion of broadcast systems that could ensure plurality of views at local, regional, and national levels?

RQ2: To what extent regulatory bodies were independent of government control while framing effective rules and policies to achieve their objectives? 
To find a plausible academic response to similar questions, researchers have used case study method [loosely defined] to analyze the politics of regulation due to its flexible approach in evaluating evolution, role, and performance of organizations (Napoli, 2003). The case study is a useful qualitative technique to study individuals, events and organizations (Horton \& Hunt, 1984), and this method has been extensively applied to study the performance of media and public sector organizations in various countries of the world. Tellis (1997) argues that examining the performance of media and government organizations was essential to discover whether media played a socially responsible role and if government policies and programs were efficient in producing desired results. Thus, a comparison of regulatory processes in India and Pakistan serves as a promising case, which could be used efficiently to establish parameters for further research.

\section{Regulatory Dilemmas in South Asia: The Case of Pakistan}

In Pakistan, the development of electronic media in the private sector kicked off in the early 1990s when the government of Benazir Bhutto allowed Shalimar Recording Company (in which government had around 50 per cent shares) to begin a channel called STN with transmitting stations in 22 cities (Tahir, 1996). The channel had its own entertainment programs, but the news was still controlled by the government (Jabbar \& Isa, 1997). The government, in 1996, granted a license to the country's first pay TV company - Shaheen Pay TV - having 50 per cent foreign equity. The company offered eight to ten channels including CNN, BBC, Sony, HBO, National Geographic, and other local channels through M MDS technology (Ali \& Gunaratne, 2000; Jabbar \& Isa, 1997). However, the company co-ventured with private entrepreneurs to establish Southern Networks, which was granted a license by PEM RA in 2004 to serve urban areas of Pakistan by offering more than 50 channels through MMDS. This is the largest pay-TV company in Pakistan with more than five million subscribers (Khan, 2008). There are also a few small pay-TV companies working in peripheral towns of Pakistan.

Similarly, satellite television was introduced in Pakistan in the middle of 1990s, but its popularity was eclipsed by the thriving cable industry, which was cheaper and easily accessible in cities and small towns. The popularity of transnational channels made telecommunication companies such as PTCL and Brain Net introduce broadband television in the urban areas of Pakistan (Khan, 2008). The establishment of a regulatory authority was, therefore, needed to facilitate and regulate a growling media market in Pakistan. In fact, the growth of electronic media has leapfrogged after the establishment of PEM RA in 2002. The unprecedented growth of electronic media in Pakistan contradicts the views expressed by Robison and Crenshaw (2002) who suggested that only democratic governments help broadcast media proliferate; but in case of Pakistan, a dictatorial regime, led by General Pervez Musharraf, helped develop an independent and considerably free electronic media under the patronage of PEM RA. Discussion in the following paragraphs critically examines the performance of PEM RA in promoting broadcast media in Pakistan.

\section{PEMRA—An I ndependent Authority}

The concept of PEM RA was envisioned by Javed Jabbar, a Pakistani media wizard, as an independent authority to license, facilitate, and regulate electronic media in Pakistan. PEM RA came into being in March 2002 through an ordinance under the supervision of Jabbar who was the Federal Information M inister. Initially, the Information M inistry oversaw the embryonic organization, but soon it was placed under the Cabinet Division to warrant 
its autonomy and impartiality. However, its autonomy was questioned when Jabbar resigned as Information Minister due to his differences with General Pervez M usharraf on issues related to freedom of media (Khan, 2008). The Information M inistry (government's public relations department) was again handed over control of PEM RA in 2007 through an amendment in PEM RA ordinance to tame the electronic media, which were overwhelmingly opposing government's anti-democratic steps (Dar, 2009). This move was heavily criticized across the country, and various journalistic organizations took out processions with members of the civil society to protest government's actions. After the imposition of emergency in Pakistan on November 3, 2007, dissident voices on television channels were silenced, and a few pro-democracy channels were blacked out. An alliance of democratic parties won the February 2008 general elections, which led to the establishment of a coalition government with Pakistan Peoples' Party as the dominant partner. Thus, PEM RA was again placed under the Cabinet Division where it is directly answerable to the prime minister. The move signified resolve of the political parties to make PEM RA independent of government control. Despite repeated promises of political leadership, PEM RA remains a subsidiary organization of the M inistry of Information. Ever since its inception, most of the responsible positions in this organization were occupied by the officials of the socalled "information service" (Khan, 2008). Thus, contrary to the views of the scholars advocating a free media, PEM RA could not emerge as a fully autonomous body, and it had employed inefficient bureaucratic approach to regulate electronic media in Pakistan.

\section{PEMRA, Diversity, and Plurality of Views}

The Pakistani government endeavored to meet public demand by establishing PEM RA, which was mandated to ensure diversity and promotion of local, and community media in Pakistan. PEM RA had pledged to empower people of Pakistan through access to diverse channels of information, education, and entertainment (Jabbar, 2003). Since minorities do not get adequate representation on the mainstream media in a multicultural society like Pakistan, local and community media controlled and operated by disadvantaged groups filled the gap. According to Harcup (2003) and Husband (2005), multiculturalism ensures the fulfillment of the needs, interests, and choices of media consumers and citizens in diverse societies. By providing citizens equitable access to communication resources and right to information, multicultural societies grow, and democratic credentials of such societies are strengthened. Thus, the concept of local and community media runs contrary to the notion of a technology-intensive professionalized media controlled by the state to promote uniformity of ideas. On the other hand, multiculturalism promotes diversity, equal representation, small-scale, localism, deinstitutionalization, horizontality of communication and close contact among members of various ethnic groups in a diverse media and the public sphere (Husband, 2005). However, PEM RA failed to ensure the development of community media in Pakistan (Ameer, 2014). Although licenses were granted to various companies for radio and television operations in peripheral areas, the lion's share of the new licenses was bestowed upon large media groups. An examination of the list of radio and television channels sanctioned by PEMRA indicates that companies headquartered in large cities applied for licenses in remote towns. It indicates the lopsided comparison of media development between urban and rural areas of Pakistan, although 65 per cent population of Pakistan constitutes what can be called a rural Pakistan.

The Pakistani case could be concluded by arguing that PEMRA worked enthusiastically to promote the growth of an independent media and it did a commendable job in the beginning; however, it was challenging for this nascent organization to materialize 160 
normative goals it had set for itself. Napoli (2003) argues that defining FCC goals is still a contested area in the U.S. Therefore, political culture, social structure, and economic constraints make it difficult for regulatory bodies to pursue their goals actively. Bureaucracies in the public relations departments are another problem in South Asia that hinders the growth of independent regulatory authorities (Napoli, 2003). In PEM RA's case, the bureaucrats belonging to the Ministry of Information and Broadcasting, responsible for the government public relations, were extremely unhappy with the establishment of an autonomous organization that could limit their authority over the burgeoning media business. Thus, PEM RA could not continue working enthusiastically as proposed by Napoli (2003) and the bureaucratic interference restricted PEM RA from following its mandate and achieving normative goals it had ardently set for itself.

\section{Regulatory Dilemmas in South Asia: The Case of I ndia}

The Indian economy along with the electronic media industry wastransformed in the early 1990s because of liberalization that was introduced in 1991. The markets were opened as the new economic policy encouraged privatization, dismantling of the control of the government and the liberalization of media regulation to encourage global players. In 1998, foreign companies started to invest and be a part of a once closed broadcasting industry and major transnational media companies such as Sony, News Corp, Discovery, MTV, CNN, and Disney were operating in India to capture the vast media market, and they were willing to change per Indian context and culture (Thussu, 1999). News Corp's Star network owned by Rupert M urdoch launched several channels in India - Star Plus, Star Movies and Star News - and began showing Western programs in English with Hindi subtitles and further moved on to locally produced programs.

In 1989, the Prasar Bharati (Broadcasting Corporation of India) Bill was introduced in the Indian Parliament. More legislator work was done on this Bill in 1990, but no government executed it until 1997. It ensured autonomy and guaranteed independence for electronic media including All India Radio (AIR) and Doordarshan (state-controlled television), which remained under government control for several decades. The Prasar Bharati Act, also specified that all property, assets, debts, liabilities, financial payments, legal proceedings involving state-controlled broadcasting would be transferred to Prasar Bharati (Ninan, 1997). The Prasar Bharati Act recommended that the Corporation would solely focus on development and maintain unity in the country through public service broadcasting. The Broadcasting Corporation ensures that all broadcasting on Doordarshan and AIR protects the interests of children, women, poor and rural sections of the population, promotes social justice, reflects the diversity and endorses social justice and national integration. While the Prasar Bharati is responsible for Doordarshan and AIR, there is no regulatory body in India yet to regulate the private channels and their broadcasting. The $M$ inistry of Information and Broadcasting currently regulates cable and satellite television under the Cable Networks Regulation Act of 1995 (see, ww w. altlawforum.org).

\section{Cable Television Networks Regulation Act, 1995}

In 1993, the India government reached out to the Cable Operators Federation of India to enact the primary regulations to facilitate the private sector broadcast media by focusing on the cable industry, which was rapidly becoming popular in all corners of India. This law helped regulate a growing cable industry in the country and allowed mass distribution of television signals to provide healthy entertainment and ensure a smooth flow of authentic 
information in different parts of the country. The law also regulates subscription rates and ensures that the free-to-air state-owned television is also provided to the subscribers as a part of the package in the basic service tier. The Cable Television Networks Rules had a Programme Code to restrict unwarranted content shown in various programs and advertisements, as these programs wield widespread influence, especially among children and teens. Some of these rules were changed in 2008, and more discussions were held several times to amend these rules further for better governance of the cable industry. Cable operators were not happy with these regulations and argued that cable industry was the only regulated part of the broadcasting sector, and they had to face many difficulties in managing the flow of content from various television channels. Likewise, implementing these laws in a vast country is a Herculean task for any democratic government in India, as cable television is available in all parts of India and enjoys tremendous popularity (see, www.infochangeindia.org).

\section{Bills that were Never Enacted}

The Broadcasting Bill of 1997 was proposed by the Ministry of Information and Broadcasting with an objective of promoting and facilitating private-sector companies in broadcasting to ensure availability of diverse and quality media content in various parts of India.

The proposed legislation sought to create an autonomous Broadcasting Regulatory Authority of India (BRAI) to facilitate broadcasting sector through an efficient system of licensing, allocate frequencies on the electromagnetic spectrum, and supervise content, pricing, and quality of the programs. The Ministry was confident that the Bill would be welcomed by various stakeholders, as it aimed at promoting Indian culture through controlling anticompetitive tendencies and ensuring the existence of a healthy media sphere. BRAI was supposed to regulate the broadcasting content for 'public interest' and would also be responsible for allocation and renewal of licenses. The Bill was never sent to the Parliament for legislation. Besides, the Indian government tried enacting the Communication Convergence Bill in 2000, which aimed at establishing one common regulatory body, Communication Commission of India (CCl), to address ICTs regulatory issues effectively. Through this bill, it was suggested that the Indian Telegraph Act 1885, the Indian Wireless Telegraphy Act 1933, the Telegraph Wire Unlawful Possession Act 1950, and the Telecom Regulatory Authority of India Act, 1997 should be rescinded. Likewise, the proposed bill addressed the continuous convergence of communication technology, but like previous efforts to establish a regulatory body, this bill remained a dead letter due to bureaucratic pressures (Joseph, 2009).

In 2006, the government made some changes to the Broadcasting Bill of 1997 and introduced the Broadcasting Service Regulation Bill. All the previous bills were discarded as the committee proposed this new bill in which the government had the authority to order any cable or broadcasting company to stop broadcasting or do it the way government suggests. The Bill also gave "Authorized officers" the authority to examine, monitor and confiscate paraphernalia of unruly broadcasters along with BRAl, as proposed in the Broadcasting Bill of 1997 (see, www.broadbandindiamagazine.com). The Bill was strongly criticized as it gave the government an undesirable power to pre-censor. The Bill was shelved when media protested due to its potential to create a negative impact on the media industry and a threat to freedom of expression (Ganguly, 1990). 


\section{To Regulate or Not to Regulate}

India has tried to enact laws to regulate the broadcasting industry for the last few decades. As successive governments finish their terms, the bills are either shelved or left at the mercy of the future government. The successive government, if from an opposition party, discourages the progress of the Bill in the House purely due to political rivalry. The media regulation bills in India are either shelved due to political rivalry or due to pressure from the broadcasting industry. The broadcast industry voiced their concerns regarding rules proposed in various Bills and content code, especially rules related to the television news (Joseph, 2009).

The review and assessment of the existing and proposed regulations in India for broadcast media suggests that the government public relations bureaucratic pressure and politics comes in the way of the formulation of broadcast policy in India. The lawmakers seem to be continually contemplating if the fourth estate of the Indian democracy should be regulated or not. The Indian government and the broadcasting industry do not seem to have an agreement when it comesto establishing a regulatory authority for the broadcasting industry. Although there is Cable Networks Regulations Act (1995) for cable television and Prasar Bharati in place to regulate the state television and radio, there seems to be no consensus on a standard regulatory body for the entire broadcasting and telecommunications industry. While the Indian government attempts to regulate the broadcasting industry with the various proposed bills and ordinances, the media industry revolts against them by defining government actions as an effort to curb the freedom of press.

\section{Conclusion}

As we have seen in both the case of India and Pakistan, bureaucracy seems to overpower the need for regulation over and over. Both India and Pakistan, who have the same colonial inheritance, also have some of the same bureaucratic issues that need to be dealt with. Pakistan has a regulatory body for the broadcasting industry, which is hardly effective in doing its work due to political influence. India is still struggling to establish a regulatory authority. Unlike other developed countries, the two countries are grappling with political issues that hinder the process discourse of public interest. The real issues relating to media remain unattended. The media industry is proliferating but the media policy and regulation is still at a nascent stage. There are ideological clashes between the federal and the state governments to come to consensus with a national policy for broadcasting. Some also question the need for regulation in a country like India, which is world's largest democracy, as it might curb the freedom of the press. At the same time, with multinationals and foreign players entering the market, it is crucial that there is necessary regulation in place to ensure the broadcasting is for genuine public interest. It looks impossible to have a proposed independent regulatory authority to exist in these countries as the powermongers try to ensure that they become a part of the regulatory regime.

Different studies (Bagdikian, 2004; McQuail, 2005; Napoli, 2003) suggest that governments want to maintain their control over electronic media due to their ubiquity and power to influence public opinion. Despotic and democratic regimes indulge in efforts to control the media due to these reasons. Scholars have also argued that democratic regimes are more prone to develop an independent media and regulatory bodies; however, in case of Pakistan, it was interesting to note that PEM RA was established dictatorial 
regime and electronic media enjoyed unprecedented growth during the military rule of Pervez M usharraf. It is equally interesting to note that India has yet to establish a regulatory body despite being an active democracy. The common factor between both societies is the control of public relations bureaucracies that thwart all endeavors, which limit their authority. Thus, as proposed by Napoli (2003) and McQuail (2005), regulatory bodies zealously work to facilitate broadcast media growth; however, lethargic bureaucracies take over as regulatory regimes challenge the status quo. It could be concluded that much political effort is required to ensure the existence of independent and autonomous regulatory bodies to facilitate the smooth functioning and development of broadcast media in India and Pakistan.

\section{References}

Ameer, S. (2014). Bureaucracies and media regulation in Asia. Manila: Orient Publishers.

Ali, O. A. \& Gunaratne, S. A. (2000). Pakistan. In S. A. Gunaratne (Ed.), Handbook of the media in South Asia (pp 155-181). New Delhi: Sage.

Anderson, C. W. (1992). The place of principles in policy analysis. In J. M. Gillroy \& M. Wade (Eds.), The moral dimension of public policy Choice: Beyond the M arket paradigm (pp. 387409). Pittsburgh: University of Pittsburgh Press.

Aufderheide, P. (2007). Communication policy and the public interest. In D. Graber (Ed.), Media power in politics (pp. 364-375). Washington D.C: CQ Press.

Bagdikian, B. (2004). The media monopoly. Boston: Beacon Press.

Ball, M. S. (1985). Lying down together: law, metaphor and theology. Madison: University of Wisconsin Press.

Bernstein, M. (1955) Regulatory business by independent commissions. Princeton: Princeton University Press.

Castells, M. (2004). The information age: economy, society, and culture. New Jersey: WileyBlackwell.

Chalaby, J. (2005). From internationalization to transnationalization. Global media and communication, 1(1), 28-32.

Corn-Revere, R. (1993). Economics and media regulation. In A. Alexander, J. Owers, \& R. Carveth (Eds.), Media Economics: Theory and practice (pp. 71-90). Hillsdale, NJ: Erlbaum.

Creech, K. C. (2013). Electronic media law and regulation. London: Routledge.

Dar, N. (2009, October 25). Information revolution in Pakistan. The Nation. p. 16.

Freedman, D. (2008). The Politics of Media Policy. Cambridge: Polity Press.

Garry, P. M. (1994). Scrambling for protection: The new media and the first amendment. Pittsburgh: University of Pittsburgh Press.

Gunaratne, S. A. (Ed.). (2000). Handbook of the media in South Asia. New Delhi: Sage.

Gunaratne, S. A. (1999). The media in Asia: An overview. International Communication Gazette. 61(3) 197-223

Gunkel, D. J. (1998). The rule of metaphor: prolegomena to any future Internet regulation. Electronic Journal of Communication, 8(2).

Harcup, T. (2003). The unspoken-said': The journalism of alternative media. Journalism, 4(3), 356-376.

Husband, C. (2005). Minority ethnic media as communities of practice: professionalism and identity politics in interaction. Journal of Ethnic and Migration Studies, 31(3), 461-479. 
ITU (International Telecommunication Union). (1998, 19999). World telecommunication development report. Geneva: ITU.

Jabbar, J. (2003, September 19) Community-base radio and TV. Dawn. p. 5.

Jabbar, J. \& Isa, Q. F. (Comps.). (1997). Mass media laws and regulations in Pakistan - And a commentary from historical perspective. Singapore: AM IC.

Javed, M. M. (2002). Regulation, competition, and information. The Pakistan Development Review, 41(4), 911-913.

Joseph, A. (2009, June 20). Broadcast regulation in the public interest: A backgrounder [Online]. Info change India. Available (http://infochangeindia.org/Media/ Broadcast-Laws-and-Regulations/Broadcast-regulation-in-the-public-interest-Abackgrounder.html)

Kemal, A. R. (2002) Regulatory framework in Pakistan. The Pakistan Development Review, 41(4), 319-332.

Khan, R. Q. (2008, June 30). Development of electronic media in Pakistan. The Post, p. A6.

Kitley, P. (2003). Television, regulation and civil society in Asia. London: Routledge.

Kohli-Khandekar, V. (2008). The Indian media business. New Delhi: Sage.

Kumar, K. J. (1995). Media education, communications and public policy: An Indian perspective,

Bombay: Himalaya Publishing House.

Kumar, K. J. \& Thomas, A. O. (2006). Telecommunications and development: The cellular mobile 'Revolution' in India and China. Journal of Creative Communications, 3 (1), 297-309

Laffont, J. J., \& Tirole, J. (1993) A theory of incentives in regulation and procurement. Cambridge, MA: M IT Press.

LeDuc, D. R. (1988). The plight of the "public interest": A principle lost in the process. Journal of Media Law \& Practice, 4, 130-143.

Ludes, P. (2008). Convergence and fragmentation. Chicago: Intellect Books.

McChesney, R. W. (2008). The political economy of media: enduring issues, emerging dilemmas. New York: Monthly Review press.

McQuail, D. (2005). M ass communication theory. New Delhi: Sage.

Mehta, A. (1998). Media regulation in India. Media Asia, 25(2), 109-112.

Napoli, P. M. (2003). Foundations of communication policy: principles and processes in regulation of electronic media. Cresskill, NJ: Hampton Press.

Olson, M. (1982). The rise and decline of nations: Economic growth, stagflation and social rigidities. New Haven: Yale University Press.

Owen, B. M. (1978). The economic view of programming. Journal of Communication, 28(2), 43-50.

Oxley, M. G. (1993). The cable-telco cross-ownership prohibition: First amendment infringement through obsolescence. Federal Communication Law Journal, 46, 7-37.

Pakistan Electronic M edia Regulatory Authority. (n.d.). Retrieved June 14, 2015, from http:/ / www.pemra.gov.pk/index.html

Price, M. E. (2008). Governance, globalism and satellites. Global Media and Communication, $4(3), 245-259$.

Rantanen, T. (2007). Flows and contra-flows in transitional Societies. In D. K. Thussu (Ed.), Media on the Move: Global Flow and Contra-Flow. New York: Routledge.

Rasul, A. (2004). Role of radio in development: The case of Pakistan. Journal of Mass Communication, 11(2), 54-67. 
Rasul, A., \& McDowell, S. D. (2011). Regulation and media monopoly: A case study of broadcast regulation in Pakistan. Retrieved from https://www.econstor.eu/ bitstream/10419/52339/1/673080374.pdf

Rasul, A., \& Proffitt, J. M. (2013). Diversity or homogeny: Concentration of ownership and media diversity in Pakistan. Asian Journal of Communication, 23(6), 590-604.

Rasul, A., \& McDowell, S. D. (2014). Consolidation in the name of regulation: The Pakistan Electronic Media Regulatory Authority (PEMRA) and the concentration of media ownership in Pakistan. Global Media Journal - American Edition, 12(20).

Richter, A. (2016). Defining media freedom in international policy debates. Global M edia and Communication, [Advance online publication]. Doi: 1742766516652164.

Robison, K. K. \& Crenshaw, E. M. (2002). Post-industrial transformations and cyber-space: A cross- national analysis of internet development. Social Science Research, 31, 334-363.

Shields, P. \& M uppiddi, S. (1996). Integration, the Indian State and Star TV: Policy and theory issues. Gazette, 58, 1-24

Smith, C. R. (Ed.). (1989). The diversity principle: friend or foe of the First Amendment? Washington, D.C: The Media Institute.

Stigler, G. (1971). The theory of economic regulation. Bell journal of economics, 2, 3-21.

Tahir, S. N. (1996). Television in Pakistan: An overview. In D French and M. Richards (Eds.), Contemporary Television: Eastern perspectives (pp. 113-131). New Delhi: Sage.

Tellis, W. (1997). Introduction to case study. The Qualitative Report, 3(2), 54-67.

Thomas, P.N. (1999). Trading the nation: multilateral negotiations and the fate of communications in India. Gazette. 61 (3). 275-292.

Thussu, D. K. (1999). Privatizing the airwaves: The impact of globalization on broadcasting in India. Media Culture and Society, 21, 125-132.

Werbach, K. (1997). The digital tornado: The Internet and telecommunications policy. Federal Communication Commission, Office of Plans and Policy Working Paper \# 29. Washington, D.C: Federal Communication Commission.

Dr. Azmat Rasul is a postdoctoral research fellow in the School of Communication at Florida State University, USA. His research interests include effects of social and entertainment media and broadcast regulation and policy. 